\title{
Microbial quality of utility water at universities in Nigeria
}

\author{
Olorunjuwon Omolaja Bello ${ }^{1 *}$, Mathew Olujenyo Oni², Temitope Kudirat Bello ${ }^{3}$, Muibat Omotola Fashola ${ }^{4}$ and \\ Yinka Doris Oluwafemi ${ }^{1}$
}
${ }^{1}$ Department of Biological Sciences, University of Medical Sciences, Ondo City, Nigeria.
${ }^{2}$ Department of Biological Sciences, Adeleke University, Osun State, Nigeria.
${ }^{3}$ Department of Biological Sciences, Southwestern University, Ogun State, Nigeria.
${ }^{4}$ Department of Microbiology, Lagos State University, Nigeria.
Email: juwonbello@yahoo.com; obello@unimed.edu.ng

Received 19 July 2019; Received in revised form 22 December 2019; Accepted 28 April 2020

\begin{abstract}
Aims: Water is described as safe and wholesome when it is free from pathogenic microorganisms and chemical substances that are hazardous to human health. This study aimed to investigate the microbial quality of water used for drinking, cooking, bathing and other purposes at universities in Nigeria.

Methodology and results: Water samples were collected from forty-four storage tanks across four selected universities. Total viable bacteria in the water samples were cultivated using the plate count agar. The isolation of total coliform and Escherichia coli were carried out on Harlequin ${ }^{\mathrm{TM}}$ E. coli/coliform agar (HA) medium, while media-faecal coliform was used for faecal coliform employing the membrane filtration technique. Physicochemical parameters such as alkalinity, $\mathrm{pH}$, total alkalinity, total dissolved solid, total suspended solid, electrical conductivity, total hardness, fluoride and chloride ion concentrations, were evaluated in accordance with standard procedures. Data were compared statistically using MedCalc statistical software. Considering the heterotrophic bacterial counts, all water samples were unsatisfactory. For the total coliform counts, $50 \%$ of samples were satisfactory but suspicious, while remaining $50 \%$ were unsatisfactory. Faecal coliforms results showed that $50 \%$ of samples gave excellent quality, $25 \%$ showed satisfactory but suspicious quality, while $25 \%$ showed unsatisfactory result. There were no significant differences in the total viable, total coliform and $E$. coli counts of water sampled from universities A and $D(p>0.05)$. The predominant bacterial species was Pseudomonas aeruginosa (23.17\%), while the least encountered was Salmonella typhimurium (2.44\%). All physicochemical parameters tested were within the acceptable limit.

Conclusion, significance and impact of study: This study revealed that the water used by students of studied universities was contaminated with potential bacterial pathogens. However, all physicochemical parameters tested were within the permissible standard limits and satisfied the requirements for domestic utility.
\end{abstract}

Keywords: Bacteriological quality, coliforms, public health, storage tank, water

\section{INTRODUCTION}

Water is an important element for the survival of all living organisms (Bello et al., 2017). The need to assess, improve and maintain the acceptable microbial quality of water cannot be overemphasized because of the enormous usefulness of water in all communities (local or urban). Water is useful for drinking and other potable purposes, such as food preparation; it is an essential hygiene substance in child and adult care and treatment of illness (breast feeding, preparation of infant foods and oral rehydration solutions, drug preparation and administration) and thereby reduce disease transmission. The importance of microbiologically safe and wholesome water for these purposes should be apparent and this is majorly in reducing the risks of enteric diseases, including diarrhoea and other waterborne infectious diseases (Chalchisa et al., 2017).

In the contrary, unsafe water is the chief source of pathogen exposure and increased risk of waterborne infection, illness and ultimately, death. Hence, the provision of microbiologically safe water has the potential to reduce the infectious burden of the developing world's population, especially students' population across the various educational institutions (from kindergarten through tertiary) in Nigeria. Recent estimates posit this situation at 4 billion cases of diarrhea and 2.2 million deaths annually, and which occurred mostly in children (US EPA, 2018). The ability of this health-related intervention to reduce the infectious disease burden of the user population to improve microbial quality is a compelling reason to accept and promote safe storage 
and treatment of collected water.

World Health Organization (WHO) (2018) reported that in 2015 , the percentage of the world population that used a safely managed drinking-water service - that is, one located on premises, available when needed, and free from contamination, was $71 \%$ (5.2 billion people). It further mentioned that $89 \%$ of the world population $(6.5$ billion people) used at least a basic service. An improved drinking-water source within a round trip of $30 \mathrm{~min}$ to collect water is referred to as a basic service. It is, however, worrisome that 844 million people lack even a basic drinking-water service, including 159 million people who are dependent on surface water; minimum of 2 billion people use a drinking water source contaminated with faeces, and by 2025 , half of the world's population will be living in water-stressed areas (WHO, 2018).

A number of studies pointed out that the lack of awareness as regards the significance of maintaining clean and hygienic stored water contributes to increasing waterborne diseases (Bello et al., 2017; Andersson et al., 2018; Mark et al., 2019; Rubino et al., 2019). Indicator bacteria have been employed, historically, to determine the possible presence of fecal contamination and measure the amount of contamination in water, including foods and other samples. There is a preference of the detection of indicator bacteria over direct pathogen detection based on the fact that the former are considered to be normal, non-pathogenic intestinal inhabitants that are present in feces and wastewater in much higher numbers, and are technically easier to detect and quantitate than the latter microorganisms. Current standards for the sanitary quality of water with respect to fecal contamination are based on concentrations of indicator bacteria.

The microbial quality of water is influenced by fecal matter, domestic and industrial sewage and agricultural and pasture runoff, in addition to a lack of hygienic practices and education among the users. Escherichia coli is an important indicator of fecal contamination of water, and it remains the determinant of water quality worldwide (Rubino et al., 2019). This study was carried out to investigate the microbial quality of utility water at selected universities in Ondo State, Nigeria.

\section{MATERIALS AND METHODS}

\section{Study area}

University of Medical Sciences, Ondo City; Wesley University Ondo, Ondo City; Federal University of Technology, Akure and Elizade University, Ilara-Mokin, all in Ondo State, Nigeria were selected for this study.

\section{Sample collection and transportation}

Borehole water samples were collected from forty-four storage tanks across the four universities under study. The selection was based on representation of locations of the universities. The major source of water supply for the selected universities was underground water channeled to water tanks around the students' hostels and other utilities. The water samples for laboratory investigations were collected according to the American Public Health Association (APHA, 1998) sampling guidelines on the standard operating procedures for bacteriological examination of water and wastewater. From each university hostel and utility, up to $100 \mathrm{~mL}$ of water sample was aseptically and separately collected from different taps in sterile plastic cup, and with up to $400 \mathrm{~mL}$ suspended in a $500 \mathrm{~mL}$ round bottom flask sealed with aluminium foil. This represented the bulk water sample from each study site. Each sample collected was preserved in a light-proof insulated ice chest with icepacks to ensure that the microorganisms remained viable though dormant. The samples were then transported immediately to the microbiology laboratory for bacteriological analyses. The four universities under study were labeled A, B, C and D. Prior to the investigation, prepared questionnaires were administered to the students and some members of staff to determine the utilities of water from the tanks.

\section{Microbiological analysis}

\section{Total viable count determination}

The viable bacteria counts were determined using modifications of standard pour plate method with plate count agar (PCA; Oxoid) as previously described by Wohlsen et al. (2006). Briefly, $1 \mathrm{~mL}$ of the water sample (from the well agitated bulk) was introduced into an empty sterile plate, and $15 \mathrm{~mL}$ of molten PCA, which had been cooled to $45^{\circ} \mathrm{C}$, was added and swirled to mix well. The mixture was allowed to cool and solidify on a flat table top undisturbed. The media were incubated at $37^{\circ} \mathrm{C}$ for $24 \mathrm{~h}$. All bacteria colonies appearing on the media surface and embedded in the media were counted with the aid of a magnifying lens.

\section{Total coliform and E. coli determination}

Bacteriological quality of the water samples was carried out employing the standard membrane filtration technique as described by Bello et al. (2013). This was done by filtering a $100 \mathrm{~mL}$ quantity of water sample through a 47 $\mathrm{mm}$ microsep membrane filter paper of $0.45 \mu \mathrm{m}$ pore size. The membrane filter was removed from the filtration cup with the use of sterile forceps and transferred to Petri dish containing Harlequin ${ }^{\mathrm{TM}}$ E.coli/coliform agar $(\mathrm{HA})$ medium by rolling action to prevent air bubbles from forming at the membrane-medium interface. The plate was incubated at $37^{\circ} \mathrm{C}$ for $24 \mathrm{~h}$. Coliforms appeared as rose-pink colonies on the HA plate while $E$. coli was detected as blue-green colonies on the HA plate. The total number of bacterial colonies was determined using BOECO colony counter and expressed as colony forming units (CFU) per $100 \mathrm{~mL}$.

\section{Faecal coliform determination}

A $100 \mathrm{~mL}$ of water sample was made to pass through the 
filter paper as described above. The membrane filter was removed with the aid of a sterile forceps and transferred onto media-faecal coliform which was incubated at $44^{\circ} \mathrm{C}$ for $24 \mathrm{~h}$. Faecal coliforms appeared as blue colonies on the media-faecal coliform agar plate. The total numbers of colonies appearing on each plate were counted and recorded. The total number of bacterial colonies was also determined with the use of BOECO colony counter and expressed as colony forming units (CFU) per $100 \mathrm{~mL}$.

\section{Identification of bacterial isolates}

Pure cultures of isolates were Gram-stained and subjected to the pertinent biochemical tests in accordance with standard procedures. These tests included catalase, coagulase, indole production, citrate utilization, urease production, hydrogen sulfide $\left(\mathrm{H}_{2} \mathrm{~S}\right)$ production and lactose fermentation tests. Acid and gas production on triple sugar iron (TSI) or Kligler Iron Agar (KIA) and motility tests were also carried out.

\section{Determination of physicochemical parameters of water samples}

Determination of alkalinity using phenolphthalein indicator

Three drops of phenolphthalein indicator was added to 50 $\mathrm{mL}$ of each of the water samples. The sample was titrated with $0.02 \mathrm{~N} \mathrm{H}_{2} \mathrm{SO}_{4}$ to $\mathrm{pH} 8.3$ and phenolphthalein alkalinity was estimated (phenolphthalein indicator was changed color from pink to colorless at $\mathrm{pH}$ 8.3). The phenolphthalein alkalinity of water was then determined as follows:

Phenolphthalein alkalinity (mg/L) as $\mathrm{CaCO}_{3}=$

$$
\frac{A 1 \times N \times 50 \times 1000}{V}
$$

Where $\mathrm{A} 1=$ Volume of $\mathrm{H}_{2} \mathrm{SO}_{4}(\mathrm{~mL}) ; \mathrm{N}=$ Normality of $\mathrm{H}_{2} \mathrm{SO}_{4}$ used to titrate, and $\mathrm{V}=$ Volume of sample used $(\mathrm{mL})$.

\section{Determination of $\mathrm{pH}$}

The $\mathrm{pH}$ of each water sample was measured with portable field $\mathrm{pH}$ meter.

\section{Determination of total alkalinity (TA)}

Three drops of bromocresol green indicator was added to $50 \mathrm{~mL}$ of water sample and titrated with $0.02 \mathrm{~N} \mathrm{H}_{2} \mathrm{SO}_{4}$ to $\mathrm{pH} 6$ and total alkalinity estimated (color changed from blue to yellow at $\mathrm{pH} 6$ ). The amount of acid consumed at the point of reaction with hydroxide, carbonate and bicarbonate. Total alkalinity was then calculated as follows:
Total alkalinity $(\mathrm{mg} / \mathrm{L})$ as $\mathrm{CaCO}_{3}=$

$$
\frac{A 2 \times N \times 50 \times 1000}{V}
$$

$\mathrm{A}_{2}=$ Volume of $\mathrm{H}_{2} \mathrm{SO}_{4}$ consumed $(\mathrm{mL}) ; \mathrm{N}=$ Normality of $\mathrm{H}_{2} \mathrm{SO}_{4}, \mathrm{~V}=$ Volume of sample $(\mathrm{mL})$.

Determination of total dissolved solid (TDS), total suspended solid (TSS) and total solid (TS)

For the determination of total suspended solid (TSS), 100 $\mathrm{mL}$ of the water sample was filtered through a preweighed filtered paper. The filtered papers, with the filtrates, were dried at $103-105^{\circ} \mathrm{C}$ in oven and TSS was determined by the following formula:

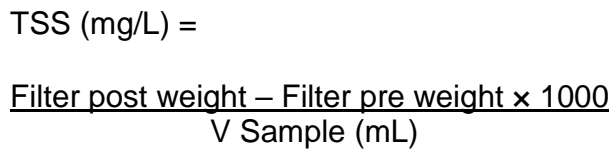

TDS was determined using combined PT 146 waterproof $800 \mathrm{pH} /$ Temperature/TDS and conductivity meter (Palintest Ltd, England), in accordance with standard manufacturer's instruction.

TS was measured from the two parameters of TDS and TSS as given by:

$$
\mathrm{TS}(\mathrm{mg} / \mathrm{L})=\operatorname{TDS}(\mathrm{mg} / \mathrm{L})+\mathrm{TSS}(\mathrm{mg} / \mathrm{L})
$$

Determination of electrical conductivity (EC)

This was measured with use of combined TDS/conductivity meter. The probes were rinsed with sterile distilled water before measurement and the probe was then immersed in beaker containing water sample. This was agitated to free the electrodes from any bubbles. Each sample was observed, and data recorded.

\section{Determination of chloride ion}

A $10 \mathrm{~mL}$ of each water sample was measured in a conical flask. The $\mathrm{pH}$ was measured and adjusted in between 7 and $9.1 \mathrm{~mL}$ of $5 \%$ potassium chromate $\left(\mathrm{K}_{2} \mathrm{CrO}_{4}\right)$ indicator was then added and titrated with previously standardized silver nitrate solution to obtain a brick-red color precipitate end point. The volume of titrant utilized was symbolize as V1. Similarly, a blank titration was done by taking $10 \mathrm{~mL}$ of distilled water (in place of sample) and the same procedure was repeated and recorded as the final volume (V2).

Finally, the concentration of chloride present in the sample was calculated using the following equation:

Chloride ion concentrations $(\mathrm{mg} / \mathrm{L})$ as $\mathrm{CaCO}_{3}=$

$$
\frac{(\mathrm{V} 2-\mathrm{V} 1) \times 35.5 \times 1000}{\mathrm{~V}_{\text {sample }}}
$$


Where $\mathrm{V} 1$ = Consumed volume of titrant for water sample; V2 = Consumed volume of titrant consumed for blank, $\mathrm{N}=$ Normality of silver nitrate and $\mathrm{V}_{\text {sample }}=$ Sample volume $(\mathrm{mL})$.

\section{Determination of total hardness of water}

This was determined by measuring and transferring 20 $\mathrm{mL}$ of the water sample into a sterile conical flask. A total of $5 \mathrm{~mL}$ ammonia-ammonium chloride buffer solution and 2-3 drops of Eriochrome Black-T indicator was added, and the color of the solution turned wine-red. This solution was titrated against previously standardized EDTA solution taken in the burette to obtain a color change from wine red to sky blue, which indicated the end point. The final reading on the burette was taken and the titration was repeated to get concordant value. The total hardness of water sample was also determined in terms of $\mathrm{mg} / \mathrm{L}$ of $\mathrm{CaCO}_{3}$, using the analytical calculation.

\section{Potentiometer determination of fluoride}

Working standard fluoride solutions were prepared from stock fluoride solution by dissolving $2.21 \mathrm{~g} \mathrm{NaF}$ in a 1000 $\mathrm{mL}$ polystyrene volumetric flask with deionised water. Sodium fluoride was oven dried at $105^{\circ} \mathrm{C}$ for $1 \mathrm{~h}$ and stored in dessicator. Then a series of standard solutions ranged from 0.05 to $10 \mathrm{mg} / \mathrm{L}$ of concentration were prepared by appropriate diluting of the stock solution to obtain a calibration curve. Total ionic strength adjustment buffer (TISAB) was also prepared by taking $58 \mathrm{~g}$ sodium chloride, $30 \mathrm{~g}$ of sodium nitrate and $57 \mathrm{~cm}^{3}$ glacial acetic (ethanoic) acid dissolving in $500 \mathrm{~cm}^{3}$ distilled water. Before final dilution, $\mathrm{pH}$ value of mixed buffer solution was adjusted to 5.50 with $5 \mathrm{~mol} / \mathrm{dm}^{3}$ of sodium hydroxide solution. After regulating $\mathrm{pH}$ values, received solution was put into $1 \mathrm{dm}^{3}$ measuring glass and filled with distilled water to measurement line. For the determination of fluoride in the water samples, $25 \mathrm{~cm}^{3}$ of the prepared TISAB buffer was added to each of the $25 \mathrm{~cm}^{3}$ of water samples and each of the series of standard solutions, the magnetic nucleus was inserted and the string speed was adjusted. Electrode was put into the solution and after five minutes, the standard solution potential was measured, according to which calibration curve was constructed. Measurements were in triplicates.

\section{Statistical analysis}

Data were compared statistically using MedCalc statistical software version 17.2 (a statistical software package designed for the biomedical sciences). Comparative statistics were computed, and data analyzed using oneway analysis of variance (ANOVA) and independent ttest (Bello et al., 2019).

\section{RESULTS}

Table 1 shows the respondents' utility of water in selected universities in Ondo State, Nigeria. Over four hundred questionnaires were distributed to students and staff of each of the universities under study. However, 395, 400, 392 and 393 completed questionnaires, making a total of 1580 were recovered from university $A, B, C$ and $D$, respectively. Out of 1580 respondents, 727 (46.01\%) used the water for drinking purpose, while all (100\%) respondents submitted that the water was used for cooking, bathing and washing purposes. The bacteria counts $\left(\log _{10} \mathrm{CFU} / 100 \mathrm{~mL}\right)$ in water at selected universities in Ondo State Nigeria were shown in Table 2. The mean total viable counts (TVC) of water samples ranged from $2.5 \times 10^{2}$ to $3.7 \times 10^{2} \quad \mathrm{CFU} / 100 \mathrm{~mL}$. Universities $A, B, C$ and $D$ had mean TVC of $3.7 \times 10^{2}$, $2.5 \times 10^{2}, 2.8 \times 10^{2}$ and $3.4 \times 10^{2} \mathrm{CFU} / 100 \mathrm{~mL}$, respectively. The mean total coliform count (TCC) ranged from $0.3 \times 10$ to $2.7 \times 10 \mathrm{CFU} / 100 \mathrm{~mL}$; the mean faecal coliform count (FCC) ranged from 0 to $1.2 \times 10 \mathrm{CFU} / 100 \mathrm{~mL}$ while the mean $E$. coli count ranged from 0 to $0.5 \times 10 \mathrm{CFU} / 100 \mathrm{~mL}$. There were no significant differences in the TVC, TCC and $E$. coli counts of water sampled from universities $A$ and D ( $p>0.05)$. The FCC of samples from universities $A$ and $D$ showed statistical difference $(p<0.05)$. Samples from university $B$ showed no significant difference from university $C(p>0.05)$ in terms of TVC, TCC, FCC and $E$. coli counts.

Microbial water quality standard for household water

Table 1: Respondents' utility of water in selected universities in Ondo State, Nigeria.

\begin{tabular}{cccccc}
\hline Utility & \multicolumn{5}{c}{ Subjects } \\
\cline { 2 - 6 } & $\begin{array}{c}\mathrm{A} \\
(\mathrm{n}=395)\end{array}$ & $\begin{array}{c}\mathrm{B} \\
(\mathrm{n}=400)\end{array}$ & $\begin{array}{c}\mathrm{C} \\
(\mathrm{n}=392)\end{array}$ & $\begin{array}{c}\mathrm{D} \\
(\mathrm{n}=393)\end{array}$ & Total N (\%) \\
\hline Drinking & $107(29.09 \%)$ & $215(53.75 \%)$ & $209(53.32 \%)$ & $196(49.87 \%)$ & $727(46.01 \%)$ \\
Cooking & $395(100 \%)$ & $400(100 \%)$ & $392(100 \%)$ & $393(100 \%)$ & $1580(100 \%)$ \\
Bathing & $395(100 \%)$ & $400(100 \%)$ & $392(100 \%)$ & $393(100 \%)$ & $1580(100 \%)$ \\
Washing & $395(100 \%)$ & $400(100 \%)$ & $392(100 \%)$ & $393(100 \%)$ & $1580(100 \%)$ \\
\hline
\end{tabular}


Malays. J. Microbiol. Vol 16(5) 2020, pp. 353-363

DOI: http://dx.doi.org/10.21161/mjm.190534

Table 2: Bacterial counts $\left(\log _{10} \mathrm{CFU} / 100 \mathrm{~mL}\right.$ ) of utility water in selected universities in Ondo State, Nigeria.

\begin{tabular}{|c|c|c|c|c|}
\hline \multirow{2}{*}{ University } & \multicolumn{4}{|c|}{ Bacterial counts (CFU/100 mL) } \\
\hline & $\begin{array}{l}\text { Total viable count } \\
\text { (TVC) }\end{array}$ & $\begin{array}{l}\text { Total coliform count } \\
\text { (TCC) }\end{array}$ & $\begin{array}{l}\text { Faecal coliform count } \\
\text { (FCC) }\end{array}$ & E. coli count \\
\hline$A$ & $\begin{array}{l}3.1 \times 10^{2} \\
2.9 \times 10^{2} \\
5.2 \times 10^{2} \\
\end{array}$ & $\begin{array}{l}2.8 \times 10 \\
2.9 \times 10 \\
2.4 \times 10 \\
\end{array}$ & $\begin{array}{r}1.1 \times 10 \\
1.1 \times 10 \\
1.4 \times 10 \\
\end{array}$ & $\begin{array}{l}0.2 \times 10 \\
0.1 \times 10 \\
0.6 \times 10\end{array}$ \\
\hline Mean* & $3.7 \times 10^{2 a}$ & $2.7 \times 10^{a}$ & $1.2 \times 10^{\mathrm{a}}$ & $0.3 \times 10^{a}$ \\
\hline $\mathrm{B}$ & $\begin{array}{l}2.7 \times 10^{2} \\
2.2 \times 10^{2} \\
2.6 \times 10^{2} \\
\end{array}$ & $\begin{array}{l}0.2 \times 10 \\
0.8 \times 10 \\
0.9 \times 10 \\
\end{array}$ & $\begin{array}{l}0 \\
0 \\
0\end{array}$ & $\begin{array}{l}0 \\
0 \\
0\end{array}$ \\
\hline Mean* & $2.5 \times 10^{2 b}$ & $0.6 \times 10^{b}$ & 0 & 0 \\
\hline C & $\begin{array}{l}3.2 \times 10^{2} \\
2.4 \times 10^{2} \\
2.8 \times 10^{2} \\
\end{array}$ & $\begin{array}{l}0.7 \times 10 \\
0.1 \times 10 \\
0.2 \times 10\end{array}$ & $\begin{array}{l}0 \\
0 \\
0\end{array}$ & $\begin{array}{l}0 \\
0 \\
0\end{array}$ \\
\hline Mean* & $2.8 \times 10^{2 b}$ & $0.3 \times 10^{b}$ & 0 & 0 \\
\hline $\mathrm{D}$ & $\begin{array}{l}3.1 \times 10^{2} \\
3.7 \times 10^{2} \\
3.5 \times 10^{2}\end{array}$ & $\begin{array}{l}2.2 \times 10 \\
2.8 \times 10 \\
2.4 \times 10\end{array}$ & $\begin{array}{l}0.7 \times 10 \\
0.5 \times 10 \\
0.2 \times 10\end{array}$ & $\begin{array}{l}0.3 \times 10 \\
0.6 \times 10 \\
0.6 \times 10\end{array}$ \\
\hline Mean* & $3.4 \times 10^{2 a}$ & $2.5 \times 10^{a}$ & $0.5 \times 10^{b}$ & $0.5 \times 10^{\mathrm{a}}$ \\
\hline
\end{tabular}

${ }^{\star}$ Mean data with same superscript along same column showed no significant difference at $95 \%$ level of confidence $(p<0.05)$.

Table 3: Microbial water quality standard and assessment for household water as per WHO $(2008,2017)$ guidelines.

\begin{tabular}{|c|c|c|c|}
\hline $\begin{array}{l}\text { Microbial counts } \\
\text { (CFU/100 mL) }\end{array}$ & $\begin{array}{c}\text { Samples within } \\
\text { category } \\
(\mathrm{N}=12)(\% \text { Positive) }\end{array}$ & Implicated university & Water quality category \\
\hline \multicolumn{4}{|c|}{ Heterotrophic bacterial count } \\
\hline $\begin{array}{c}0 \\
1-10 \\
11-30 \\
31-100 \\
>200\end{array}$ & $\begin{array}{c}0 \\
0 \\
0 \\
0 \\
12(100 \%)\end{array}$ & $\mathrm{A}, \mathrm{B}, \mathrm{C}$ and $\mathrm{D}$ & $\begin{array}{c}\text { Excellent } \\
\text { Satisfactory/Suspicious } \\
\text { Unsatisfactory } \\
\text { Unsatisfactory } \\
\text { Unsatisfactory }\end{array}$ \\
\hline $\begin{array}{c}\text { Total coliform count } \\
0 \\
1-10 \\
11-30 \\
31-100 \\
>200\end{array}$ & $\begin{array}{c}0 \\
6(50 \%) \\
6(50 \%) \\
0 \\
0\end{array}$ & $\begin{array}{l}B \text { and } C \\
A \text { and } D\end{array}$ & $\begin{array}{c}\text { Excellent } \\
\text { Satisfactory/Suspicious } \\
\text { Unsatisfactory } \\
\text { Unsatisfactory } \\
\text { Unsatisfactory }\end{array}$ \\
\hline $\begin{array}{c}\text { Faecal coliform cour } \\
0 \\
1-10 \\
11-30 \\
31-100 \\
>200 \\
\end{array}$ & $\begin{array}{c}6(50 \%) \\
3(25 \%) \\
3(25 \%) \\
0 \\
0 \\
\end{array}$ & $\begin{array}{l}B \text { and } C \\
\text { D } \\
A\end{array}$ & $\begin{array}{c}\text { Excellent } \\
\text { Satisfactory/Suspicious } \\
\text { Unsatisfactory } \\
\text { Unsatisfactory } \\
\text { Unsatisfactory } \\
\end{array}$ \\
\hline
\end{tabular}


Malays. J. Microbiol. Vol 16(5) 2020, pp. 353-363 DOI: http://dx.doi.org/10.21161/mjm.190534

Table 4: Morphological and biochemical characteristics of bacteria isolated from utility water in selected universities in Ondo State, Nigeria.

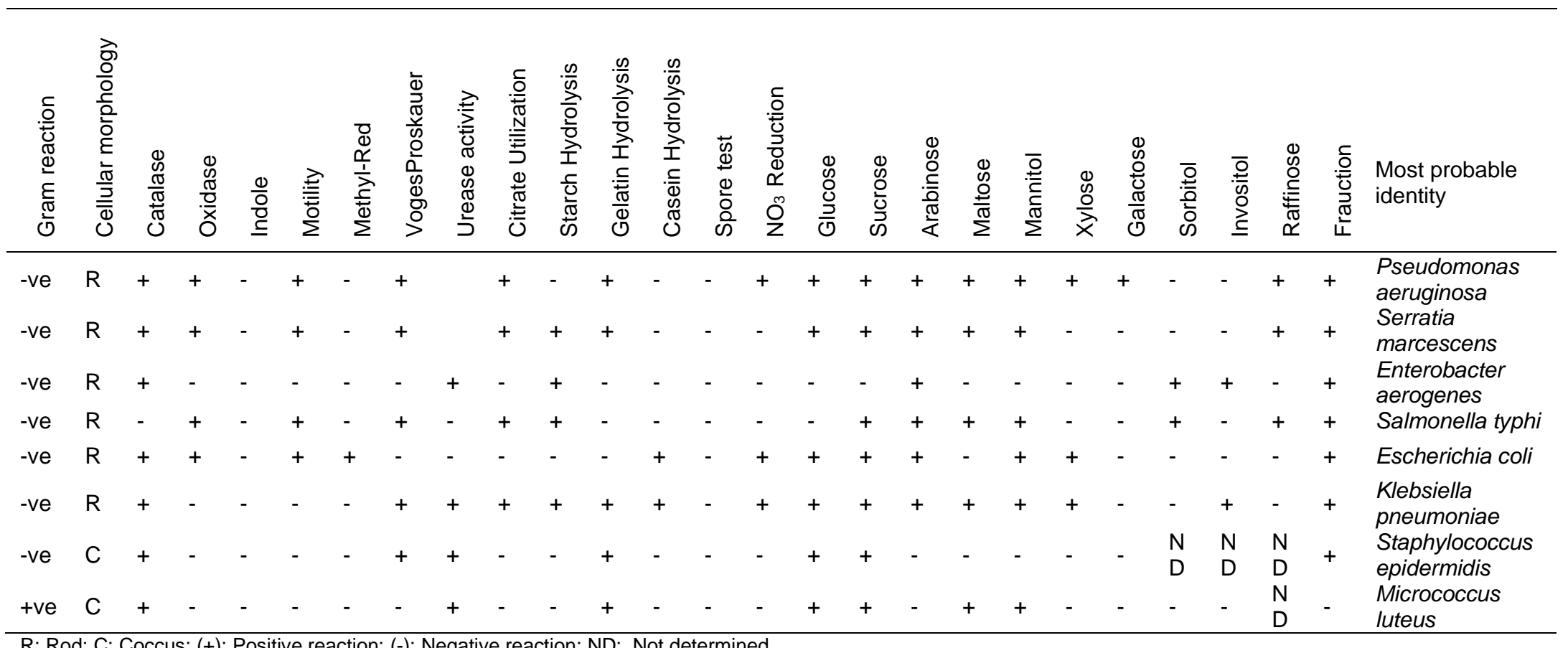

R: Rod; C: Coccus; (+): Positive reaction; (-): Negative reaction; ND: Not determined 
tank in accordance with WHO guidelines was shown in Table 3. This showed that, considering the heterotrophic bacterial counts, all the water samples $(100 \%)$ from the universities were unsatisfactory as they had colony counts $>200$ in every $100 \mathrm{~mL}$ of the samples. For the total coliform counts, it was indicated that samples from universities $B$ and $C$ were satisfactory but suspicious, while remaining those from $A$ and $D$ were unsatisfactory. Considering the presence of faecal coliforms, results showed that samples from universities $B$ and $C$ gave excellent quality, samples from university $D$ showed satisfactory but suspicious quality, while A showed unsatisfactory result.

Table 4 shows the morphological and biochemical characteristics of bacteria isolated from utility water in selected universities in Ondo State, Nigeria. Eight genera of bacteria were encountered and these were identified as Enterobacter aerogenes, Escherichia coli, Klebsiella pneumoniae, Pseudomonas aeruginosa, Salmonella typhimurium, Serratia marcescens, Staphylococcus epidermidis and Micrococcus luteus.

Figure 1 shows the percentage occurrence of bacteria isolated from utility water in selected universities in Ondo State, Nigeria. The predominant bacterial species was $P$. aeruginosa with percentage occurrence of $23.17 \%$, followed by $E$. aerogenes $(19.51 \%)$, S. marcescens $(14.60 \%)$, K. pneumoniae (13.42\%), E. coli (8.54\%), M. luteus $(7.32 \%)$ while the least encountered was $S$. typhimurium $(2.44 \%)$

Table 5 shows the physicochemical analysis of utility water in selected universities in Ondo State, Nigeria. The mean $\mathrm{pH}$ of the water samples from the four universities under investigation ranged from 6.57 to 7.28 ; total hardness ranged from 6 to $12 \mathrm{mg} / \mathrm{L}$; turbidity ranged from 1.12 to 1.19 NTU; total alkalinity (TA) ranged from 88.60 to 181.20 ; total dissolved solid (TDS), total suspended solid (TSS), total solid (TS) and electrical conductivity ranged from 11 to $24 \mathrm{mg} / \mathrm{L}, 11.14$ to $15.00 \mathrm{mg} / \mathrm{L}, 139.62$

Table 5: Physicochemical analysis of utility water in selected universities in Ondo State, Nigeria.

\begin{tabular}{|c|c|c|c|c|c|}
\hline \multirow{2}{*}{ Parameter } & \multirow{2}{*}{$\begin{array}{l}\text { WHO standard } \\
(2010) ; \\
\text { US EPA (2018) }\end{array}$} & \multicolumn{4}{|c|}{ Universities* } \\
\hline & & $A$ & $\mathrm{~B}$ & $\mathrm{C}$ & $\mathrm{D}$ \\
\hline $\mathrm{pH}$ & $6.5-8.5$ & $6.60^{a} \pm 0.01$ & $6.57^{a} \pm 0.01$ & $7.28^{b} \pm 0.02$ & $6.90^{\mathrm{b}} \pm 0.1$ \\
\hline Total hardness & $500 \mathrm{mg} / \mathrm{L}$ & $8.00^{a} \pm 0.05$ & $6.00^{a} \pm 0.03$ & $12.00^{\mathrm{b}} \pm 0.07$ & $7.00^{a} \pm 0.06$ \\
\hline Turbidity & $5 \mathrm{NTU}$ & $1.14^{\mathrm{a}} \pm 0.03$ & $1.12^{a} \pm 0.01$ & $1.19^{a} \pm 0.02$ & $1.16^{a} \pm 0.02$ \\
\hline Phenolphthalein alkalinity & $20 \mathrm{mg} / \mathrm{L}$ & ND & ND & ND & ND \\
\hline TA & $500 \mathrm{mg} / \mathrm{L}$ & $92.00^{a} \pm 0.10$ & $88.60^{a} \pm 0.62$ & $181.02^{b} \pm 0.10$ & $181.02^{a} \pm 0.10$ \\
\hline TDS & $500 \mathrm{mg} / \mathrm{L}$ & $20.00^{\mathrm{a}} \pm 0.52$ & $18.00^{b} \pm 0.34$ & $11.00^{c} \pm 0.23$ & $24.00^{d} \pm 0.38$ \\
\hline TSS & $\leq 30$ & $11.14^{a} \pm 0.83$ & $13.00^{a} \pm 1.30$ & $12.00^{a} \pm 0.91$ & $15.00^{b} \pm 1.22$ \\
\hline TS & 500 & $163.57^{a} \pm 0.72$ & $139.62^{\mathrm{b}} \pm 0.67$ & $158.40^{c} \pm 0.90$ & $221.91^{d} \pm 0.63$ \\
\hline EC & 400 & $200.00^{a} \pm 0.07$ & $217.20^{\mathrm{b}} \pm 0.06$ & $214.90^{\mathrm{b}} \pm 0.06$ & $235.72^{c} \pm 0.05$ \\
\hline Free chlorine & $0.5 \mathrm{mg} / \mathrm{L}$ & $0.10^{a} \pm 0.00$ & $0.10^{\mathrm{a}} \pm 0.0$ & $0.10^{a} \pm 0.00$ & $0.10^{a} \pm 0.00$ \\
\hline Nitrate & $50 \mathrm{mg} / \mathrm{L}$ & $3.00^{a} \pm 0.02$ & $2.00^{a} \pm 0.01$ & $4.00^{a} \pm 0.02$ & $4.00^{a} \pm 0.02$ \\
\hline Iron & $300 \mu \mathrm{g} / \mathrm{L}$ & $13.7^{a} \pm 0.12$ & $15.3^{a} \pm 0.16$ & $20.1^{b} \pm 0.19$ & $16.5^{a} \pm 0.13$ \\
\hline Fluoride & $1.5 \mathrm{mg} / \mathrm{L}$ & $0.21^{b} \pm 0.01$ & $0.09^{a} \pm 0.00$ & $0.13^{c} \pm 0.01$ & $0.18^{d} \pm 0.01$ \\
\hline Manganese & $400 \mu \mathrm{g} / \mathrm{L}$ & $355.00^{b} \pm 1.82$ & $320.00^{a} \pm 1.35$ & $390.00^{c} \pm 2.00$ & $331.00^{\mathrm{a}} \pm 1.85$ \\
\hline
\end{tabular}

TA: Total alkalinity; TDS: Total dissolved solid; TSS: Total suspended solid; TS: Total solid; ND: Not detected; EC: Electrical conductivity

*Data represents mean value of three replicate samples. Data with same superscript along same row showed no significant difference at $95 \%$ level of confidence $(p \leq 0.05)$ 
to $235.72 \mathrm{mg} / \mathrm{L}$ and 200.00 to $235.72 \mathrm{mg} / \mathrm{L}$, respectively. The detectable free chlorine in all water samples was 0.1 $\mathrm{mg} / \mathrm{L}$. The concentration of nitrate in the water samples ranged from 2 to $4 \mathrm{mg} / \mathrm{L}$, iron ranged from 13.7 to 20.1 $\mu \mathrm{g} / \mathrm{L}$; fluoride ranged from 0.09 to $0.21 \mathrm{mg} / \mathrm{L}$ while manganese concentration ranged from 320 to $390 \mu \mathrm{g} / \mathrm{L}$. It is worthy to mention that phenolphthalein alkalinity was not detected in all samples, and that all physicochemical parameters investigated on the water samples from the different universities fell within the acceptable quantities.

\section{DISCUSSION}

The appearance, smell or taste of water is not usually clearly changed by bacterial contamination. The only way to detect if water contains coliform bacteria is to carry out bacteriological examination on the water. There could be numerous potential pathogens in water, and each requires a different method of detection. It is, however, impractical and expensive to test water for all the microorganisms. Instead, testing for indicator bacteria is the most ideal means of determining whether or not a water supply is free from microbial contamination. The coliform group, which includes the total coliform, fecal coliform and $E$. coli, are usually the three different types of indicator bacteria tested for. Positive detection of any of these subgroups has a different level of public health risk to human.

Bacterial infections are transmittable by water via the faecal-oral route. From this study it was observed that $46.01 \%$ of the residents in the selected universities used the water for drinking purpose while $100 \%$ used it for cooking, bathing and washing purposes. As a matter of fact, $53.75 \%$ and $53.32 \%$ (over half) of respondents at university $\mathrm{B}$ and $\mathrm{C}$, respectively, submitted that they utilized the water for drinking purpose (Table 1).

The four universities under study used borehole as their main water source, but the water was mostly stored in water storage tanks via which the water got distributed for utilities by students. It is reasonable to submit that an accumulation of sediments in water tanks could serve as sources of nutritional supply for proliferation of bacteria. The bacteria counts in water used by the university students varied in quantity and quality which could be directly associated with hygienic practices translating to care of the storage tanks themselves before thinking of the percolation of other microbial contaminants through sewage and agricultural run-offs.

The mean total viable counts (TVC) of water samples ranging from $2.5 \times 10^{2}$ to $3.7 \times 10^{2} \mathrm{CFU} / 100 \mathrm{~mL}$ indicted all samples for the presence of heterotrophic bacteria beyond the acceptable level as evaluated against the microbial water quality standard for household water tank as per WHO guidelines (WHO, 2018); though, the counts varied from one university to the other. The mean TCC, FCC and $E$. coli counts also varies per university. It is believed by most people that borehole water have a high quality not taking into account the possibility of potential contamination, especially when the water has to be stored in storage water tank and get distributed through the pipe-

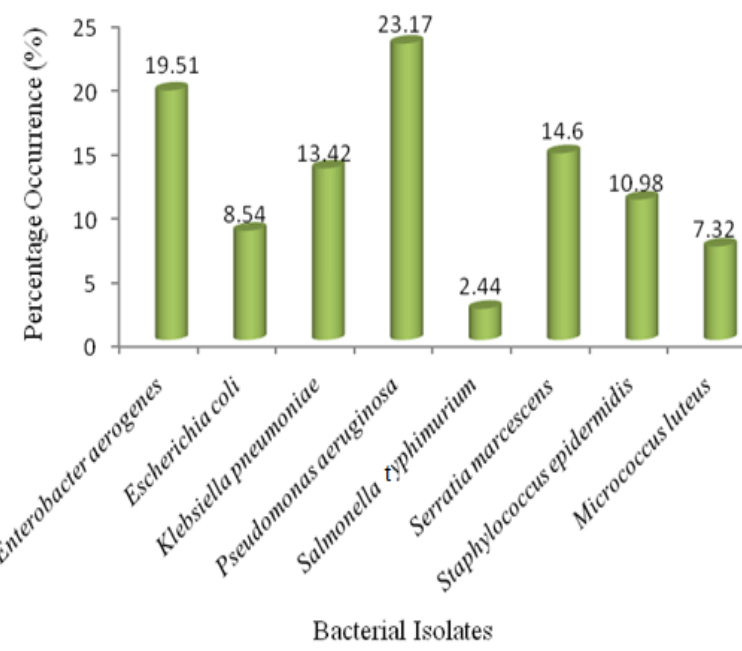

Figure 1: Percentage occurrence of bacterial species isolated from water used by students of selected universities in Ondo State, Nigeria

borne system. This water source could be potentially deteriorated by biological and chemical products in distribution systems. Many adverse human health effects could be potentially caused by several microbial and chemical contaminants of drinking water (WHO, 2018). It should, however, be noted that water storage tanks and reservoirs could pose high challenge on water utilities as they often have a negative effect on water quality, yet they are critical features of distribution systems.

From bacteriology standpoint, samples from universities $B$ and $C$ were satisfactory but suspicious in terms of the total coliform counts, while those of universities $A$ and $D$ were unsatisfactory. Universities $B$ and $C$ showed excellent water quality in terms of the presence of faecal coliforms; university $D$ showed satisfactory but suspicious water quality while university $A$ was unsatisfactory as per WHO (2017) guidelines for drinking water quality. The rate at which the water storage tanks used by the universities were washed or cleaned could be also be responsible for the high total viable bacteria count encountered in this study. This was buttressed by a similar work of Chalchisa et al. (2017) who reported that emptying and cleaning of storage water tanks is one procedure which can significantly reduce the microbial contamination of the stored water. Therefore, topping up of storage water tanks with water from the borehole source could have direct impact of the microbial quality of the water samples in terms of total viable bacteria, total coliform, faecal coliform and E. coli counts. This had also contributed to the diversity of bacteria encountered in this study in different frequency at the different universities.

The result of this study is similar to the submission of Zaqoot et al. (2016) in their study on storage water tanks in Palestine, who recorded a low to high total coliforms (1-100 CFU/100 mL). Meride and Ayenew (2016), in their 
study on drinking water samples from different protected sources in Wondo Genet, reported high coliform level. The authors reported that total coliforms were present in each water sample collected from protected sources and storage tanks, and which deviated from maximum permissible limits of the WHO (Rubino et al., 2019). This finding is, however, contrary to the result of Calchisa et al. (2017) who submitted that all water samples investigated were contaminated and none met the WHO maximum permissible limit of drinking water quality. The authors attributed this poor water quality to leakage and contamination in the distribution system and/or unsafe storage. This necessitates the need for regular inspection for a provision of microbe-free drinking water to communities. According to WHO (2017) guidelines for drinking-water quality, total coliforms should not to be detected in any water intended for drinking.

Kanth et al. (2018) implicated 9 out of 12 samples as unsuitable for drinking from bacteriology point of view while also reporting the presence of Staphylococcus, Klebsiella and Salmonella spp. in the study. It was also reported by Agbo et al. (2019) that a higher percentage of drinking water samples were not bacteriological fit for consumption as the authors submitted that some brands of bottled, sachet and borehole water samples contained potential pathogens in their study within Calabar Municipality. Roohul et al. (2012) also isolated E. coli from $20 \%$ of the samples analyzed and reported that the water contamination could be associated with leakage in pipes and cross contamination from waste waters.

Schafer and Mihelcic (2012) submitted that the material and size of storage water tank possess a significant effect on the quality of water while Aish (2013) reported that lesser contamination occur in water stored plastic storage tanks as compared to that stored in stainless steel. Water stored in the large water storage tanks could be contaminated with total coliforms, considering the size of the tanks, due to the longer storage times, and this could potentially increase the risk of contamination and allow chlorine to volatilize (Khan and AIMadani, 2017). Furthermore, contrary to the finding of this study with the occurrence of faecal coliform count of $12 \mathrm{CFU} / 100 \mathrm{~mL}$, Akuffo et al. (2013) reported a higher faecal coliform counts (up to $250 \mathrm{CFU} / 100 \mathrm{~mL}$ ) in drinking water samples collected from storage water tanks in Ghana.

The organisms encountered in this study had also been implicated in the drinking water supply in rural settings in Kenya as reported by Sila (2019). Khan and AIMadani (2017) in their study on the assessment of microbial quality in household water tanks in Dubai, United Arab Emirates isolated similar organisms but belonging to four genera which included $P$. aeruginosa, Salmonella gallinarum, $E$. coli and Enterobacter aerogenes. The authors also reported $P$. aeruginosa has the most occurred microorganisms. Similarly, Peter and Routledge (2018) reported that $P$. aeruginosa were found widely predominant in soil and stagnant water, and which were capable of infecting humans and plants. The organism does not normally cause illness in immunocompetent healthy people but can cause serious infections in immunosuppressed hosts. Infection of the lung could lead to pneumonia; serious tissue damage may result from infected burns or wounds, and "necrotising enterocolitis" may also arise as a result of the infection of the gastro-intestinal system (Sousa and Pereira, 2014). Kennedy (2012) also associated the growth of Pseudomonas in drinking water to the ability of the organism to colonize biofilms in plumbing fixtures.

Those students at universities $A$ and $D$ where a higher number of microbial contaminants were encountered could experience some itching leading to some bacterial skin infections; these might be often traced to the water used for bathing and washing purposes. Therefore, contamination of the water from storage tanks with coliform bacteria and most importantly faecal coliform and $E$. coli raise a public health concern. The presence of $E$. coli in the water indicates the water had been contaminated with matter of faecal origin. Drinking water polluted with faeces can expose the human body to various water borne diseases and therefore the water needs to be treated before using for any domestic purpose.

The physicochemical parameters in this study were all within the WHO maximum permissible limit of drinking water (WHO 2017; 2018). Agbo et al. (2019) also reported similar physicochemical parameters of sachet and bottled water falling in close ranges with those obtained in this study. Yasin et al. (2015) reported $\mathrm{pH}$ of water samples in the range of 7.4-8.14. However, Meride and Ayenew (2016) and Yasin et al. (2015) reported a low turbidity value (0.98 NTU) in their study on water samples collected from Wondo Genet. The clarity of water is an important determinant of its utility. All water samples were clear and odourless. The measure of intensity of acidity or alkalinity of water and the concentration of hydrogen ion is referred to as $\mathrm{pH}$. This parameter is useful to determine the safety of water for drinking and irrigation purposes. Total hardness of water is an important parameter to determine the suitability of water for domestic and industrial uses. Multivalent metallic cations alongside certain anions present in the water are responsible for hardness of water (Sila, 2019).

Chlorides are found in all types of waters. However, its presence in high concentration is considered as indictors of pollution usually as a result of organic wastes of animal or industrial origin. The findings in this study are comparable with the reports of Nirmala et al. (2013) and Dinesh and Rajesh (2013). Concentration of fluoride $(F)$ is an important aspect of hydrogeochemistry and has immense impact on human health. Low $\mathrm{F}$ content is responsible dental caries, while high concentration $(>1.20 \mathrm{mg} / \mathrm{L})$ results in fluorosis. High intake of fluorides may also result into gastrointestinal imbalances such as loss of appetite, vomiting, nausea, ulceric pain, constipation and intermittent diarrhea and flatulence (Katta et al., 2015).

Nitrate and phosphate evaluations are important in assessing the potential biological productivity of surface waters. High concentrations of these elements could aid 
proliferation of microorganisms in water. Total dissolved solids (TDS) of water represent the organic matter and inorganic salts in water that could due to the presence of elements such as calcium, magnesium, carbonates, sodium, potassium, sulfate and nitrate, hydrogen carbonate and ions of chloride (WHO, 2018). High level of TDS usually occurs due to sea water intrusion and increased salt content. Total Hardness is as a result of the presence of calcium and magnesium salt. Total alkalinity is the quantitative capacity of an aqueous medium to react with $\mathrm{H}^{+}$ions (Katta et al., 2015).

This study has some limitations. Testing drinking water samples for the presence of coliforms before storage was not carried out, and how long the water was stored before sampling was not known; whereas, this study could be important to detect which point the water gets contaminated during distribution. This should give an insight whether the water has been contaminated from source or probably, the treatment process was not sufficient to eliminate the microorganisms. This is a problem in developing countries where microbial contamination of protected drinking water is widespread. The term "protected water" made international estimates to greatly overstate access to safe drinking water and calls for enhanced monitoring strategy combining indicators of sanitary protection with measures of water quality.

\section{CONCLUSION}

This study revealed that the water used by students of the studied universities was contaminated with potential bacterial pathogens. This poses a health risk on the ground that a high percentage of the students in the selected universities utilized the water for drinking and cooking purposes. Furthermore, this study provides information about the physicochemical status of water in selected universities in Ondo State, Nigeria. It was determined that all physicochemical parameters tested were within the permissible standard limits and satisfied the requirements for domestic utility.

\section{FUNDING SOURCE}

This research did not receive any specific grant from funding agencies in the public, commercial, or not-forprofit sectors.

\section{COMPETING INTEREST}

Author declared no potential conflict of interest exists.

\section{REFERENCES}

Agbo, B. E., Ogar, A. V., Akpan, U. L. and Mboto, C. I. (2019). Physico-chemical and bacteriological quality of drinking water sources in Calabar Municipality, Nigeria. Journal of Advances in Microbiology 14(4), 1 . 22.
Aish, A. M. (2013). Drinking water quality assessment of the Middle Governorate in the Gaza Strip, Palestine. Water Resources and Industry 4, 13-20.

Akuffo, I., Cobbina, S. J., Alhassan, E. H. and Nkoom, M. (2013). Assessment of quality of water before and after storage in the Nyankpala community of the Tolon-Kumbungu District, Ghana. International Journal of Scientific and Technology Research 2(2), 221-227.

American Public Health Association, APHA (1998). Standard methods for the examination of water and wastewater (20th edn.). American Public Health Association, Washington, D.C.

Andersson, K., Otoo, M. and Nolasco, M. (2018). Innovative sanitation approaches to address multiple development challenges. Water Science and Technology 77(4), 855-858.

Apin Public Health Initiatives. Ondo State Office. https://apin.org.ng/ondo-state/ [Retrieved on 4 April 2019].

Bello, O. O., Oni, M. O., Bello, J. O. and Bello, T. K. (2019). Incidence of extended-spectrum betalactamase producing bacteria in salad vegetables in Ondo city, Nigeria. Asian Food Science Journal 9(1), 1-14.

Bello, O. O., Oni, M. O., Bello, T. K. and Amoo, O. T. (2017). Occurrence of antibiotic-resistant bacteria in sachet and bottled water brands in Ondo City, Nigeria. International Journal of Advanced Research and Publications 1(6), 58-67.

Bello, O. O., Osho, A., Bankole, S. A. and Bello, T. K. (2013). Bacteriological and physicochemical analyses of borehole and well water sources in ljebu-Ode, southwestern Nigeria. IOSR Journal of Pharmacy and Biological Sciences 8(2), 18-25.

Chalchisa, D. Megersa, M. and Beyene, A. (2017). Assessment of the quality of drinking water in storage tanks and its implication on the safety of urban water supply in developing countries. Environmental Systems Research 6,12.

Dinesh, P. A. and Rajesh, P. G. (2013). Study of some physicochemical parameters of drinking water sources in Tembhurkheda and Jarud Region Dist.Amaravati, MS, India. International Research Journal of Environment Sciences 2(10), 93-95.

Kanth, K. M., Singh, S. K., Kashyap, A., Vijay Kumar Gupta, V. K., Shalini, S., Kumari, S., Kumari, R. and Puja, K. (2018). Bacteriological assessment of drinking water supplied inside the Government schools of Patna District, Bihar, India. American Journal of Environmental Protection 6(1), 10-13.

Katta, J., Govindan, R., Nagaraju, N. and Basavaraj, R. (2015). Bacteriological and physicochemical analysis of drinking water samples in and around Javaranahalli, Mandya, Karnataka. International Journal of Current Research 7(1), 12006-12010.

Kennedy E. (2012). Mutability and survival of Pseudomonas aeruginosa in multi-species drinking water biofilm communities. Phd Thesis. University of Southampton, England. 
Khan, M. A. and AlMadani, A. M. A. A. (2017). Assessment of microbial quality in household water tanks in Dubai, United Arab Emirates. Environmental Engineering Research 22(1), 55-60.

Mark, Y. A., Amoah, P., Nelson, A. W., Muspratt, A. and Aikins, S. (2019). Safety assessment on microbial and heavy metal concentration in Clarias gariepinus (African catfish) cultured in treated wastewater pond in Kumasi, Ghana. Environmental Technology 40(3), 302-311.

Meride, Y. and Ayenew, B. (2016). Drinking water quality assessment and its effects on residents health in Wondo genet campus, Ethopia. Environmental System Research 5, 1.

Nirmala, B., Suchetan, P. A., Darshan, D., Sudha, A. G., Lohith, T. N., Suresh, E. and Mamtha. (2013). Physico-chemical analysis of selected ground water samples of Tumkur District, Karnataka. International Journal of ChemTech Research 5(1), 288-292.

Peter, A. and Routledge, E. (2018). Present-day monitoring underestimates the risk of exposure to pathogenic bacteria from cold water storage tanks. PLOS ONE 13(4), e0195635.

Roohul, A., Ali, S. S., Anwar. Z. and Khattak, J. Z. K. (2012). Microbial analysis of drinking water and distribution system in new urban Peshawar. Current Research Journal of Biological Science 4(6), 731-737.

Rubino, F., Corona, Y., Pérez, J. G. J. and Smith, C. (2019). Bacterial contamination of drinking water in Guadalajara, Mexico. International Journal of Environmental Research and Public Health 16(67), 111.

Schafer, C. A. and Mihelcic, J. R. (2012). Effect of storage tank material and maintenance on household water quality. American Water Works Association 10(49), 49-50.

Sila, O. N. (2019). Physico-chemical and bacteriological quality of water sources in rural settings, a case study of Kenya, Africa. Scientific African 2, e00018.

Sousa, A. M. and Pereira, M. O. (2014). Pseudomonas aeruginosa diversification during infection development in cystic fibrosis lungs - a review. Pathogens 3, 680-703.

US EPA (2018). Drinking Water Standards and Health Advisories Tables. EPA 822-F-18-001 Office of Water U.S. Environmental Protection Agency Washington, DC.

WHO (2008). Guidelines for drinking-water quality. WHO, Geneva:http://www.who.int/water sanitation health/d wq/fulltext.pdf [Retrieved on 4 May 2019].

WHO (2010). Global WASH Fast Facts. http://www. cdc.gov/healthywater/global/wash statistics.html. [Retrieved on 5 May 2019].

WHO (2017). Guidelines for drinking-water quality, 4th edition, incorporating the 1st addendum. https://www.who.int/water sanitation health/publicatio ns/drinking-water-quality-guidelines-4-including-1staddendum/en/ [Retrieved on 11 May 2019].

WHO (2018). Drinking water. Factsheet: https://www.who.int/news-room/fact sheets/detail/drinking-water [Retrieved on 11 May 2019].

Wohlsen, T., Bates, J., Vesey, G., Robinson, W. A. and Katouli, M. (2006). Evaluation of the methods for enumerating coliform bacteria from water samples using precise reference standards. Letters in Applied Microbiology 42, 350-356.

Yasin, M., Ketema, T. and Bacha, K. (2015). Physicochemical and bacteriological quality of drinking water of different sources, Jimma zone, Southwest Ethopia. BMC Research Notes 8, 541.

Zaqoot, H. A., Hamada, M. and El-Tabash, M. A. (2016). Investigation of drinking water quality in kindergatens of Gaza Strip Governorates. Journal of Tethys 4(2), 88-99. 